\title{
Antonio Carlos Garros Stort (1939-2005)
}

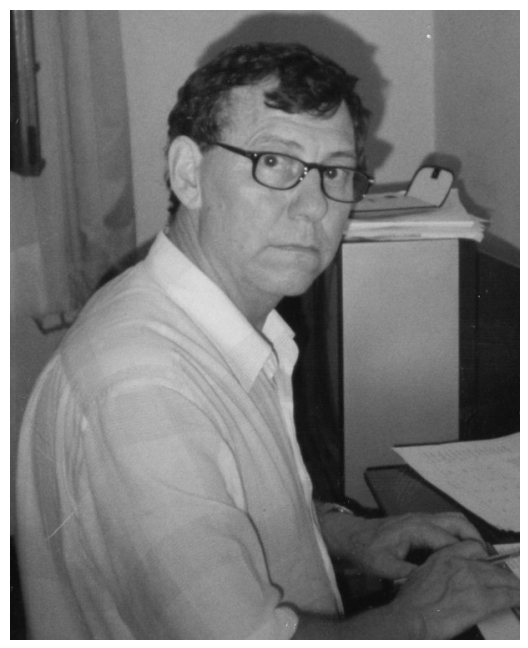

"The gentlest expert in aggressiveness I have ever known", this is how I describe my best friend and almost brother Stort.

On February $12^{\text {th }}, 2005$, all bee experts and bee lovers lost one of the world's gentlest, most easy-going and genuinely nice honey-bee researchers. Prof. Stort dedicated almost all his life to the study of the aggressiveness of Africanized bees, although he was well aware of the fact that he was extremely allergic to them, and that the bees could put an end to his life with only a few stings. However, he always had an anti-allergic medicine in his pocket, especially when he went out to perform aggressiveness tests with "his" bees.

Prof. Antonio Carlos Stort was born in Mogi Mirim, State of São Paulo, Brazil, on December 19, 1939, the son of Antonio Stort and Maria Helena Garros Stort. He left behind his wife, Prof. Dr. Maria Neisa Silva Stort, a daughter, the dentist Adriana Maria Stort, and two sons, the chemical engineer Carlos Eduardo and the materials engineer Vinicio José. Prof. Stort made his undergraduate studies in Mogi Mirim and graduated in 1961 as a biologist from the Course of Natural History of the Rio Claro School of Philosophy, Sciences and Letters, nowadays the Institute of Biosciences of the São Paulo State University (UNESP) at Rio Claro, State of São Paulo.

I met Stort for the first time in 1962, when he came to a Natural History Congress in Curitiba, PR, as a graduate

Prof. Dr. Lionel Segui Gonçalves, Universidade de São Paulo, Faculdade de Filosofia, Ciências e Letras de Ribeirão Preto, Departamento de Biologia, Ribeirão Preto, SP, Brazil. E-mail: Isgoncal@usp.br. student of the bee geneticist Prof. Dr. Warwick Estevam Kerr. At this meeting, Prof. Kerr invited me to work with him too, and when I moved to Rio Claro, in 1963, I had the pleasure to share a room with Stort there, rented in a family home. Since then, our carriers as bee geneticists and our friendship have kept us close over all these years. Stort was always a very calm, happy and discreet person, even in extreme situations. I remember that in December 1964, a month before I was to leave for the USA for a year, Stort simply disappeared for about a month from Rio Claro and nobody knew where he was, not even I who used to live with him. As I had to vacate the room before traveling abroad, two days before leaving I called his parents in Mogi Mirim and was stunned to hear that Stort was in São Paulo City, in a hospital, recovering from a heart surgery performed by the famous Dr. Zerbini. I went to see him, and he simply said that, knowing the high risk of the surgery $(50 \%$ chance of survival), he had decided to inform only his parents. I was shocked by such self-control; however, I admired his calm manner of facing such a serious problem, a great example for me.

Two years after graduation (1963), Prof. Stort was invited by another geneticist, Prof. Ademar Freire-Maia, to take a permanent teaching position in Introductory Biology for Pedagogy students at the School of Philosophy, Science and Letters of Araraquara, SP. He worked there until 1978, when he was hired as a Professor by the Institute of Biosciences - UNESP at Rio Claro. During his career there, he was chairman of the Department of Biology several times, member of the Congregation, Vice-Director of the Institute, etc., until his retirement in 1993 as Full Professor. Even then, he continued working in São Carlos as a visiting professor and as a very active researcher.

Early in his career, while Prof. Stort was teaching in Araraquara, he was invited by Prof. Kerr to do his Ph.D. studies at the Bee Lab of the Genetics Department of the School of Medicine of the University of São Paulo at Ribeirão Preto, SP. There he collaborated in numerous lab projects during the first years of existence of the Department. In that lab, with Prof. Kerr as adviser, Stort and I did, at the same time, all the experimental work of our doctoral theses on Africanized honey bees. He finished his thesis entitled "Genetic study on the aggressiveness of Apis mellifera in 1972". In 1979, Stort presented his Associate Professor thesis, "Genetic study of morphological characters and their relation to defensive behavior in honey bees of the genus Apis". He was the first scientist who developed 
methods for the study of the aggressive behavior of Africanized bees; these methods are still used today all over the world. He was also the first one to describe the genes that control aggressiveness in honey bees.

In 1982, Prof. Stort reached the highest rank of his career when he obtained the title of Full Professor of Genetics at the Institute of Biosciences-UNESP at Rio Claro. During his career, Prof. Stort was an active member of several scientific societies, including the Brazilian Society of Genetics (SBG), the Brazilian Society for the Progress of Science (SBPC), and UNESCO. He was a researcher for the Brazilian Council for Scientific and Technological Development (CNPq) and USDA, and a member of the Academy of Sciences of the State of São Paulo. He trained various students on their way to their Masters' and Ph.D. titles, and had research grants from FAPESP, FUNDUNESP, CNPq, and FINEP. Along his career, he received several honors, including the Raphael Beiguelman Award for genetics. Prof. Stort also worked as adviser and scientific consultant and as a specialist in bee genetics, in several countries of South and Central America, where he gave a number of international courses on bee genetics. Prof. Stort published about 180 scientific papers (articles in journals, proceedings of congresses, etc.) in Brazilian and international specialized journals (Rev. Brasil. Biol; Rev. Brasil. Genet.; Ciência e Cultura; Euphytica, Ann. Rev Entomol.; J. Apic., Res.; J. Kansas Entomol. Soc., Behavior Genetics, etc.), 5 book chapters and 2 books, and became a world-renowned expert in honey-bee aggressiveness. I had the great pleasure to participate together with Prof. Stort in almost all of his bee program extension activities in Brazilian and international courses, congresses, consultancies, etc. This lifelong contact I had with Stort - over 40 years of friendship and collaborative work - sometimes seems to me more than a brotherhood. Based on everything I witnessed about Antonio Carlos Garros Stort as a human being, I can say that he was an outstanding example of humbleness, wisdom, honesty, a good friend, a wonderful father and a brilliant scientist - "the gentlest expert in aggressiveness I have ever known". 